Fecha de recepción: abril 2019

Fecha de aceptación: octubre 2019

Versión final: mayo 2020

\section{Marca M para Hitchcock - Dial M for Hitchcock. Los hilos y matices que se repiten en la obra del director}

Vanesa Brasil Campos Rodriguez *

Resumen: Este ensayo reúne la producción fílmica de Alfred Hitschcock con otras obras estéticas a partir de una lectura interdisciplinaria.

Palabras clave: Hitschcock - estética - tejido textual - lectura.

[Resúmenes en inglés y portugués en la página 94]

${ }^{(*)}$ Doctora en Ciencias de la Información por la Universidad del País Vasco, España. Profesora titular de UNIFACS, Universidad de Salvador, Bahía, Brasil.

"Ustedes llaman a este hombre 'Hitch', nosotros le decimos 'Monsieur Hitchcock'. Ustedes lo respetan porque filma escenas de amor como escenas de crimen. Nosotros lo respetamos porque filma escenas de crimen como si fueran escenas de amor".

François Truffaut

Este ensayo surge de la percepción de que los filmes del gran maestro del suspense, Alfred Hitchcock, poseen algunos elementos que se repiten y dialogan entre si y con otras obras estéticas y, por ello, despertaron mi atención y me han convocado para una lectura más profunda. El estudio abarca la semiótica narrativa en interfaz con el psicoanálisis, la antropología y la cultura. Señalamos las resonancias formales, estéticas y estructurales entre las obras estudiadas. En este texto, propongo iniciar el trayecto a partir de la letra " $M$ ", como la inicial que se inscribe en distintos elementos presentes en los filmes del director, tanto en la estructura, como en la forma, en los nombres de las protagonistas y de ciertos lugares, y en el motivo principal de su obra: murder, el asesinato. "M" es, otrosí, la letra inicial de movie (film, película), de movimiento, de mujer y de madre, elementos significativos de la escritura hitchcockiana.

A continuación, mostraremos otros elementos estilísticos y estructurales que se repiten en las obras del periodo hollywoodiano del director: la espiral, el abismo, los ojos y la conexión profunda de la estética de sus filmes con la pintura de Edward Hopper. Estos elementos que iremos señalando van a conformar la tesitura, -los nudos y los hilos- que, creemos, tejen su escritura, su texto, construyendo su obra fílmica. 
Nuestra metodología de análisis del discurso se define como "lectura". En el modelo de lectura que propone González Requena $(1995,1996)$, titulado “Teoría del Texto”, el analista comienza su trabajo penetrando a través de los significantes del texto (pictórico, fílmico, etc.). Partimos de los significantes en busca de los significados en sus múltiples encadenamientos. De este modo entramos en contacto con ciertos elementos fuertes que, al entrecruzarse, definen el tejido textual, la textura. La lectura posibilita una experiencia de encuentro con una red simbólica porque está tejida con símbolos que resuenan en el sujeto, en el único sujeto posible: el que está delante del texto, el que lo lee y el que lo escribe. Y lo que emerge es el sujeto del deseo, sujeto del inconsciente.

La antropología visual propone no solamente mirar las imágenes, sino también percibir el carácter cultural, implícito o subjetivo, y, de esa manera, leerlas como textos. Según Samain (2011), se debe considerar la relevancia y la posibilidad de constitución de un diálogo entre áreas afines, como el arte, la antropología y las imágenes, para que haya un entendimiento de cultura. Para el autor "es urgente recolocar el arte en el epicentro de la existencia humana, es decir, en el centro de la cultura, de todas las culturas" (Samain, 2011, p. 31).

El psicoanálisis nos da el soporte necesario para abordar una teoría del lenguaje en relación directa con la constitución de la subjetividad humana. La semiótica narrativa nos permitirá una formalización del análisis que trataremos de transcender a una teoría del relato. Calabrese (1997, p. 37) dibuja una función específica para la semiótica aplicada al campo del arte, como la pintura figurativa. El autor esclarece que disciplinas más abstractas como la semiótica "tienen la posibilidad de analizar objetos figurativos como objetos teóricos, dotados de medios metalingüísticos propios y específicos".

Calabrese (1997, p. 40) muestra la importancia de la intertextualidad en la lectura de obras de arte: "exactamente aquella de la referencia a textos que no están expresos en la propia materia de la expresión del texto inicial". El autor explica que intertexto es un conjunto de propiedades más o menos genéricas de otros textos evocados por la obra, admitiéndose que esas propiedades corresponden a textos de cualquier tipo. De esta forma, un cuadro puede remitir a una película o a una obra literaria. $\mathrm{O}$ viveversa.

Nos basamos también aquí en esta investigación en una de las máximas del historiador de arte Warburg en la que afirma que las obras de arte son las "vías de acceso para la comprensión de ciertas sutilezas de la cultura” (Teixeira, 2010, p. 139). Warburg utilizó las varias posibilidades del estudio de la imagen para comprobar su tesis: que existen elementos en las representaciones icónicas que sobreviven al tiempo y que consiguen permanecer presentes en diversos períodos de la historia.

Lo que nos convoca es el diálogo que el texto fílmico establece con el lector-espectador, es decir, llevar a cabo un recorrido penetrando por los hilos que tejen dicha tesitura. $\mathrm{O}$, en palabras de Lacan: "Lo que tenemos delante es una obra. Vamos a intentar separar las fibras con la ayuda de los aparatos que inventamos" (Lacan, 1986, p. 06).

\section{M de Hitchcock, el Maestro del suspense}

M es la letra inicial de la palabra Movie (película), de Movie Theater (cine) de Motion (Movimiento). Para mí, Hitchcock es el director más genial de la historia del cine. Sus 
filmes son verdaderas clases de cine, sus técnicas son osadas, su creación de suspense es magistral.

M es la letra de Murder (muerte violenta, asesinato, crimen). El suspense de Hitchcock marca un antes y un después en la historia del cine. El cineasta rompe con paradigmas, con los códigos del cine clásico y empieza a mostrar escenas de asesinato con elegancia, ingenio y sutileza. Pero, sobre todo, Hitchcock "filma escenas de crimen como si fueran escenas de amor", como afirma Truffaut (Truffaut, Scott, 2004). Filma y muestra la violencia, sí, que es lo propio del choque de los cuerpos, pero sin trivializarla o vulgarizarla. Es decir, el cuidado con no banalizar el tema del asesinato, con no ser demasiado explícito o gráfico, sumado al tratamiento impecable de dirección, dota a sus películas del estatuto de obras maestras. Podemos ponerlas al lado de obras literarias de suspense con el calibre de aquellas nacidas de la pluma de Edgard Alan Poe o Sir Arthur Conan Doyle. Creo que ha logrado realizar, con su obra, el sueño de los asesinos en Festín Diabólico (Rope, 1948): ¡hacer del crimen una obra de arte!

Pues

[...] las más grandes obras de arte son las que devuelven con mayor precisión, con mayor rigor y exactitud, la lógica que da sentido al modo de representación al que pertenecen y a través del cual una época se piensa y se conforma (González Requena, presentación, en Casanova Varela, 2007, 8).

Sus películas Psicosis (Psycho, 1960) y Los Pájaros (The Birds, 1963) marcan el comienzo del cine postclásico. Su ingenio anticipa, muchas veces, el cine contemporáneo al introducir nuevas técnicas en los filmes de suspense. ¿Cómo explicar que ni una sola gota de agua manche la lente de la cámara en Psicosis en un plano nadir de la ducha? Siempre por delante de su tiempo, Hitchcock filmó La llamada fatal (Dial M for Murder) en 3D, em 1953, para conseguir una mayor profundidad del escenario ${ }^{1}$ y el resultado fue extraordinario.

La letra M es la inicial del personaje fundamental de varias obras del director: Missus or Mistress (esposa o amante). Es la M de Mujer. Y, por ello, comparece también como la inicial de sus grandes protagonistas: Marion Crane, de Psicosis; Marnie, de Marnie, la ladrona; Madeleine, de Vértigo (Vertigo, 1958); Mrs. (madam, missus) Winter, la muchacha (Joan Fontaine no tiene nombre propio en la película Rebeca); Margot Wendice, de Dial M for murder, Crimen Perfecto; y Melanie, protagonista del film Los Pájaros (The Birds). Estas mujeres encarnan varias facetas de composición de los personajes femeninos: decididas, imaginarias, fantasmáticas, enigmáticas, amedrentadas, dóciles, fuertes o frágiles.

$M$ es, sobre todo, la inicial de Madre (mother), un personaje poderoso, que se impone en la gran mayoría de los filmes del director en su etapa manierista ${ }^{2}$ en Hollywood (después de 1940). La madre está presente aun cuando no se revela, como ocurre en Psicosis (1960). Ella domina, desde lo alto de la colina, la mansión de los Bates y el universo interior de su hijo. 


\section{Marion vs. la Madre Bates}

La Señora Bates, esta madre creada e incorporada en su hijo Norman, es el personaje dominante del filme. Marion Crane, la chica asesinada en la ducha del motel, es una víctima impotente delante de una madre voraz y predadora como una de las aves de rapiña que pueblan el escenario del Bates Motel. Lugar que no protege a sus huéspedes, pues fue convertido en armadilla mortífera para quien penetre y amenace la relación dual perfecta e imaginaria Norman-Señora (la Madre) Bates ${ }^{3}$.

En Psicosis (1960), el personaje Marion Crane (Janet Leigh), en un impulso, roba $40 \mathrm{mil}$ dólares para saldar las deudas de su novio. Se convierte en una ladrona, no como la protagonista compulsiva de Marnie, la Ladrona (Marnie, 1964). Marion Crane hurta una única y definitiva vez. "A lo mejor, una sola vez es lo bastante", afirma arrepentida para Norman Bates en la sala dos pájaros embalsamados. Marion solo deseaba casarse como revela en las escenas iniciales del film en su encuentro con Sam en un hotel barato de Phoenix. Ella comparece como la novia siempre a la espera del amante Sam (John Gavin) que es incapaz de asumirla. Esto la precipitará hacia un final trágico. Después del robo y la huida hacia Fairvale, el agua de la lluvia desvía a Marion hacia el Bates Motel y la obliga a detenerse en ese siniestro lugar. Se trata de un escenario apropiado para aprisionar y asesinar pequeños pájaros y a muchachas como Marion, desgarradas y desubicadas. Es significativo el pseudónimo con el que firma en el libro de registro del Motel Bates: Marie Samuels, revelando, con el apellido ficticio, su gran deseo de casarse con Sam, su endeudado novio. Marion es víctima de un Motel siempre vacío ("doce cuartos, doce plazas"). Fue asesinada bajo la ducha y su cuerpo fue depositado en las aguas sucias de un pantano cerca del motel. Un baño eterno para un sueño eterno. La muchacha es víctima de una "Madre" predadora, personalidad cultivada con esmero en la mente enfermiza de Norman Bates (Antony Perkins) su hijo matricida. Ella, la Madre siniestra, sintetiza, no solo en la escritura hitchcockiana, sino también en el ámbito de las representaciones artísticas de masas, "el reinado absoluto de una diosa loca que ha venido a ocupar, sin que nadie se diera cuenta, el lugar dejado vacante por el Dios patriarcal cuya proclamada muerte había inaugurado el siglo" (González Requena, presentación, en Casanova Varela, 2007, 25).

\section{Marnie y su Madre Meretriz}

Marnie Edgard (Tippi Hendren), la protagonista de Marnie, la ladrona (1964), comparece en el inicio de la película como una mujer fuerte, decidida y manipuladora. La mujer hurta compulsivamente y cambia constantemente de identidad. ¿Quién es Marnie? ¿Quién es aquella que está por detrás de sus múltiples disfraces? La respuesta está en su infancia, en Marnie, la nenita, la niña asustada delante de una madre siniestra, una meretriz que recibía en su propia casa a los amantes marineros mientras una asustada chiquilla oía los lamentos (rumores o chillidos del goce) maternos del otro lado de la puerta.

Poco a poco el personaje se va revelando a los ojos del espectador como una figura impotente, fóbica que, ante cualquier aparición del color rojo sobre fondo blanco, se muestra víctima de pánico y adolece de una inmovilidad que la impide de cualquier acción. Ella 
se ve obligada a casarse con Mark Rutland (Sean Connery), un empresario que ha quedado fascinado por la potencia enigmática de la mujer y su enfermedad. Pero la fobia por el color rojo la impide de disfrutar los placeres de la noche de nupcias en la que queda petrificada. A lo largo de la película, el problema de Marnie se va revelando tanto para el personaje, como para el propio espectador. Bernice Edgar (Louise Lathan), madre de Marnie, es la fuente de toda fobia de la muchacha. La niña siempre ha implorado el amor de su madre que solo tiene ojos para la hija de una vecina. Marnie se ve excluida y rechazada, hecho que queda evidente cuando busca consuelo en el regazo materno. Pero la siniestra madre niega constantemente el cariño que demanda su hija y rechaza cualquier suerte de aproximación. El regazo materno está frío y vacío, no es para ella. Siempre lo reservó para los demás: para los marineros o para la niña del otro lado de la calle. Es significativo el gesto repetitivo de Marnie sentada en el suelo intentando apoyar su cabeza en la pierna de su madre. Pero ella la desprecia.

El retorno a la casa materna en una noche de tormenta acaba por revelar la fuente del trauma reprimido. El rojo sobre fondo blanco ha traído a la superficie la sangre sobre el uniforme del marinero a quien ella, a los cinco años, asesina a golpes de atizador. Ha revivido la caída del hombre sobre el cuerpo de su madre, cuya pierna permanece, desde entonces, inutilizada para siempre. El bastón de la madre se transforma en un elemento castrador e inhibidor, ya que comparece para punir y castrar el deseo de la hija.

El horror al rojo es también el horror al sexo, al dolor del sexo y a sus entregas. La madre que, en su juventud, se ha sometido al sexo hasta sus últimas consecuencias, de alguna forma impide que la hija lo realice plenamente y le inculcó que los hombres son criaturas viles y los matrimonios, instituciones terribles. Por un lado, Marnie desarrolla una personalidad fóbica y, sin embargo, compulsiva, pues está siempre tramando planes para robar grandes sumas de los cofres de las empresas donde trabaja. Roba a los hombres a quienes anteriormente ha seducido.

\section{Madres entre venenos, pájaros y miradas heladas}

Las madres, en buena parte de las películas de Hitchcock, en el período aquí estudiado, son mujeres poderosas y terribles. Madame Sebastian (Leopoldine Konstantin), la madre de Alexander Sebastian (Claude Rains), una mujer fuerte y dominadora, ayuda a concebir un plan para envenenar poco a poco Alicia (Ingrid Bergman) con arsénico en Tuyo es mi corazón (Notorious, 1946). Otras madres de la filmografía de Hitchcock, por ejemplo, Lydia Brenner (Jessica Tandy), la madre del abogado Mitch Brenner (Rod Taylor) en Los Pájaros (The Birds, 1963), es una mujer dominadora que impide la consumación de los lazos sexuales de su hijo. La escena final del film, cuando la protagonista Melanie Daniels (Tippi Hendren) está completamente herida y sumisa a su suegra, es un ejemplo que muestra el dominio de estas madres terribles en las tramas hitchcockianas. Estas madres estarían muy próximas de las diosas terribles y mortíferas, universo trabajado por González Requena. Son elementos que emergen cuando la figura paterna, que debería encarnar la ley, sucumbe. De sus fragmentos, nace una mujer todopoderosa, avasalladora, que impide el deseo del sujeto. 
El universo hitchcockiano es un terreno fértil y propicio para la emergencia de mujeres-madres fálicas, castradoras y/o mortíferas. La Sra. Danvers, la gobernanta de Rebeca (Rebecca, 1940), tiene este estatuto de madre-fálica. La mujer aterroriza a la Sra. Winter, dominándola, subyugándola con los recuerdos de Rebeca (la anterior señora Winter), la mujer inolvidable. La fascinación que la imagen imaginaria de Rebeca ejerce en la película encuentra su mayor exponente en la figura de la Sra. Danvers. Su rostro de expresión helada y dura como la de un cadáver, siempre recordando a la que fuera la más perfecta de las mujeres, dejaba aterrorizada a la muchacha. La frialdad transmitida por la gobernanta llega al punto de contagiar a la protagonista, nunca llamada por su nombre, sino siempre por Mrs. Winter, Sra. Invierno. Sobre ello escribe Truffaut: "un rostro inmóvil y otro que lo aterroriza, la víctima y el verdugo en la misma imagen” (2004, p. 127). Hitchcock explica:

La Sra. Danvers casi no andaba, nunca se le veía desplazándose. Por ejemplo, cuando entraba en el cuarto de la protagonista, la muchacha oía un ruido y la Sra. Danvers ya estaba allí, de pie, sin moverse. Era un modo de mostrar la situación desde el punto de vista de la heroína: ella nunca sabía dónde estaba la Sra. Danvers y así era más aterrorizante; ver a la Sra. Danvers andando la habría humanizado (Hitchcock en Truffaut, Scott, 2004, p. 128).

La Sra. Danvers funciona como esta madre-siniestra, alguien que espía, acorrala, amedrenta y está siempre omnipresente. Es la figura materializada de Rebeca, su faz visible. Pero, ambas (Rebeca-Sra. Danvers) tienen un peso en escena mucho más potente que el de la protagonista, la Sra. Winter, la muchacha. González Requena la compara a la imagen de Carlota Valdés, de Vértigo (Vertigo): "figuras delgadas, estiradas y ásperas, ambas de desconfiada, fría y dura mirada”. (González Requena, Presentación, en Casanova Varela, 2007, p. 10).

La protagonista interpretada por Joan Fonteine es alguien que nunca tendrá un nombre propio en el filme, será siempre Mrs. Winter. Su marido, Maxim, como el nombre propio indica, es, para la mujer, lo máximo, y ella, lo mínimo. Minimalismo presente incluso en sus ropas simples, trajes sin cualquier detalle que la haga sobresalirse sobre las demás. El bello vestido de gala que copia del cuadro enorme de la pared no agrada a su esposo, que la rechaza en plena fiesta. En España, una chaquetita de punto que solía vestir la muchacha del film se hizo famosa y pasó a denominarse rebeca. Es significativo que la prenda no lleva su nombre, sino el de la protagonista invisible. El personaje está siempre oprimido por la imagen de la inolvidable Rebeca, por la mansión Manderley, por la obsesión de la Sra. Danvers y por la distancia de su marido.

Otra madre que comparece con estatuto de dominadora es la Sra. Thornhill, personaje de la película Intriga internacional (North by Northwest, 1959). Su aspecto siniestro no es tan evidente como el de la Sra. Danvers de Rebeca, de la madre meretriz de Marnie, o de la Sra. Bates de Psicosis, pero su presencia angustiante sobre el hijo se torna densa a partir del arranque de la película, tanto así que el protagonista la denomina perro sabueso. Como bien describe Casanova "Y sin embargo, detrás de ese acelerado arranque del film late una cita esencial, aquélla que habrá de concentrar todo el interés de Thornhill: la cita con su madre -que es también una cita con la locura" (Casanova Varela, 2007, p. 50). 
La confusión inicial del film con el cambio de identidad tiene origen en esta cita con la madre, una cita que lo absorbe a punto de equivocarse de manera irremediable. Preocupado en enviar un telegrama a su madre, Thornhill levanta la mano para llamar al botones, al mismo tiempo en que se oye por la megafonía el nombre de George Kaplan. Él comparece como Kaplan y, a partir de entonces, tendrá otra identidad: "un signo, un significante relacionado con la madre, provoca por tanto un desvarío: desde ese momento Roger se encontrará metido en una delirante historia en la que incluso se queda sin identidad" (Martin Arias, 1998, p. 15). Y su madre se convertirá en fantasma, en el fantasma de Roger: "Ella es, pues, el centro de atención de Thornhill, su figura lo domina todo, y es por tanto hacia esa figura hacia donde él dirige su deseo" (Casanova Varela, 2007, p. 96).

Por otra parte, en oposición a esta miríada de madres fuertes, los universos hitchcockianos son habitados por personajes masculinos débiles, pusilánimes, que no asumen gestos heroicos cuando para ellos son convocados. En Psicosis, Sam Loomis (John Gavin) no protege a Marion y no es capaz de pagar sus propias deudas. Esta relación que no se resuelve precipita a Marion a un viaje hacia su trágico destino final. Ni siquiera cuando la muchacha desaparece, el hombre es capaz de asumir una postura heroica. Es Lila Crane (Vera Miles) quién desvendará el crimen como una verdadera detective. Es ella quien va a solucionar todo el misterio, examinando, habitación por habitación, la mansión de los Bates hasta su encuentro con el esqueleto en el sótano.

\section{M de Madeleine, la Mujer fantasma}

Madeleine, la protagonista de Vértigo, es un personaje de una potencia avasalladora en la obra hitchcockiana. En ese filme el manierismo adquiere su punto máximo, casi bordeando lo sublime. El relato fílmico está construido en torno a un personaje imaginario que se desdobla en otros personajes, como las capas de una cebolla, o puertas que se abren a otras puertas en un infinito juego de espejos. Madeleine merece un lugar especial en este estudio. Ya, a partir de los títulos de crédito, el espectador se ve hipnotizado por una mirada que le atrapa. La cámara penetra en el interior de un ojo femenino y se zambulle en su pupila. El personaje y su enigmático poder de seducción ya están inscritos en estas imágenes iniciales del film. No se trata del cuerpo de una mujer cualquiera, sino del cuerpo de "La Mujer Ideal": absoluto, perfecto, siempre distante, intangible.

Madeleine aparece primero como la esposa de Elster (Tom Helmore), un viejo amigo de Scottie Ferguson, Johnny O (James Stewart), un detective que padece de acrofobia. Elster le pide a Scottie que vigile y siga a su esposa que él afirma que está obcecada por la imagen de la abuela Carlota Valdés, una legendaria figura que se habría suicidado como consecuencia de una crisis de locura. A la recusa inicial de aceptar el trabajo, sigue un segundo momento de fascinación por un rostro de diosa, un perfil tan perfecto y pálido como el de un camafeo lapidado con esmero en madreperla. El detective obcecado y completamente poseído por la imagen de la mujer perfecta va a perseguirla por las calles de San Francisco y entra en un vórtice laberíntico que lo conducirá a la locura.

Madeleine surge como una mujer perfecta, ideal e idealizada, elegante, con el pelo rubio casi translúcido siempre recogido en un moño en espiral. La mujer se dibuja en escena 
como alguien obcecado por la figura de Carlota Valdés, su abuela, y pasa largas horas en el museo del Palacio de la Legión de Honor de San Francisco, delante del retrato de su antepasada. La imagen del cuadro muestra a una mujer sentada con el mismo modelo de moño en espiral portando un ramo de flores en sus manos. La secuencia está construida a partir de una estructura formada por una sucesión de planos subjetivos -mirada de Scottie- y otra que es la de la mujer del cuadro, que mira al espectador desde la superficie pictórica. Como afirma Castro de Paz, se establece un juego circular de miradas extremadamente complejo:

Desde la mirada de Scottie vemos el cuadro en el que Madeleine, con su pose elegante e inmóvil y el ramo de flores sobre el banco a su izquierda, mira ensimismada el Retrato de Carlotta que, desde el lienzo, nos devuelve la mirada. Un círculo cuya mirada última -los ojos sin vida de Carlotta- nos hablan de la imposibilidad de acceder a la comprensión de un enigma de por sí inaprehensible, por fraudulento (Castro de Paz, 1995, p. 261).

El tema del cuadro dentro del cuadro, el cuadro-vivo, el cine-pintura, en suma, es uno de los elementos más significativos de la escritura hitchcockiana y del cual Vertigo constituye un modelo ejemplar ${ }^{4}$.

Volviendo al tema de la mirada de Scottie y la construcción de una mujer imaginaria y quimérica, nos concentramos ahora en la secuencia en la que Madeleine se precipita en la bahía de San Francisco, simulando un suicidio, lo que atrae al detective de forma irreversible hacia un abismo que se sitúa en un espacio más allá de la vida. $\mathrm{O}$, como afirma Trías (2006, p. 91), Vértigo es "una historia "de amor constante más allá de la muerte", para decirlo en términos de Quevedo". La mirada fascinada del protagonista, mirada vertiginosa, está presa a un abismo profundo. Lo que queremos enfatizar es que el personaje de Madeleine está construido a partir de la mirada ilusionada de Scottie. Es la imagen fantasmática de mujer que lo atrae, pues representa el propio abismo que tanto teme y desea que lo trague. Madeleine, al saltar en las aguas de la bahía encarna la muerte y construye la imagen fascinante y etérea de un fantasma. Pero antes de desplomarse ha dibujado un escenario perfecto para abrigar su cuerpo de suicida, coloreando las aguas con las flores y pétalos esparcidos de su ramo, imagen que remite inmediatamente a la pintada en el cuadro Ofelia, de Millais ${ }^{5}$. Esta caída finalmente se consolidará en la torre de la Misión española ante la mirada angustiada de un Scottie petrificado, inmovilizado por su acrofobia. La imagen del cuerpo que cae y que se precipita delante de los ojos de Scottie es un tema repetido varias veces en la película: en su arranque, el cuerpo del policía que cae del tejado; en la escena da torre de la Misión de San Juan Bautista, como la verdadera esposa de Elster; en su propio cuerpo desplomando en una espiral vertiginosa de su sueño; en la escena final, cuando Judy finalmente cae de la torre de la misión.

¿Cómo reconstruir una muerta, cómo resucitarla? Scottie parece recuperado de su crisis de locura, pero sigue como en un trance persiguiendo la imagen imaginaria de la mujer muerta, deseada e inalcanzable, recorriendo los mismos lugares que ella frecuentaba. $\mathrm{Su}$ búsqueda vertiginosa prosigue hasta encontrarse con Judy, una muchacha muy semejante a su fallecida amada. Pero no se conforma con una mujer distinta a su objeto de deseo imaginario y no descansará hasta transformarla en Madeleine, su Eurídice perdida, 
vistiéndola de gris, descolorándola, hasta que se vuelva completamente fantasmática. La escena en la que Judy-Madeleine sale del baño, envuelta en brumas, conducida por la maravillosa banda sonora de Bernard Herrmann, en una atmósfera de iluminación azulada, es embriagante. La sensación que produce en el espectador solo se compara al vértigo del beso que ocurre a continuación cuando Scottie la toma en brazos. En cuanto la cámara gira en torno de la pareja enamorada, el espectador entra en una vorágine vertiginosa proporcionada por la dirección habilidosa del mago Hitchcock y que no encuentra parámetros en la historia del cine. Una de las más bellas secuencias, en mi opinión, ya filmadas y que resume esta ilusión de un amor infinito e inmortal.

Madeleine, por tanto, comparece como una mujer moldada: primero por Elster, el marido, después por Scottie, al transformarla de Judy en la esposa muerta de Elster. La verdadera Madeleine solo comparece como un cuerpo que cae y que solo es vislumbrado a distancia. La Madeleine que nos convoca analizar es esta mujer etérea, perfecta, moldada y manipulada por personajes masculinos.

Al final, ella encarna lo que Scottie desea: una mujer perfecta, sin fallas o fisuras, sin estrías o ranuras, la imagen de la mujer primordial de sus deseos infantiles. La escena de la imagen especular de Madeleine inmersa en una profusión de colores en la floristería siendo observada por el detective, es ejemplar: "Éste no ve lo que nosotros vemos: que ella posee existencia dentro del espejo. Él no ve lo que llegará a ver, lo que todos llegaremos a ver: que su realidad es fraudulenta, como lo es toda imagen de espejo" (Trías, 2006, p. 99).

Como decíamos anteriormente, se trata de un laberinto de espejos con muchas faces que reproducen distintas imágenes especulares: Judy interpretando a una Madeleine, vagando por calles convertidas en laberintos, deambulando por museos y cementerios; la mujer que imita a Carlota Valdés en un gesto de alejamiento de la realidad, en su moño y en el buqué de flores que trae consigo; ella interpretándose a sí misma que interpreta a la mujer muerta; o como Judy cayendo realmente al vacío, su postrera caída, rumbo a la muerte. Finalmente, la mujer se convierte en fantasma.

\section{M de Margot. Simplemente La Mujer}

Con M de Muerte; La llamada fatal (Dial M for Murder, 1954) puede que no fuera el film preferido de su director, pero está entre los grandes según Scorsese. En mi opinión es la película de Hitchcock que muestra a la Mujer con la M mayúscula. El personaje de Margot (Grace Kelly) es una esposa que tiene un amante, el escritor americano Mark Halliday (Robert Cummings), y su marido, el fracasado jugador de tenis Tony Wendice (Ray Milland), teme que ella lo deje en la miseria. Él va a tramar un asesinato para recibir el seguro de vida de Margot y planea lo que supone una coartada perfecta. Tony contrata a un aventurero (Anthony Dawson) para estrangular a su mujer mientras él permanece en un club en compañía del rival. El crimen tenía todos los ingredientes para ser perfecto ya que la coartada de su inductor la proporcionaba el propio amante de la mujer.

Pero Margot lucha con todas sus fuerzas contra el agresor y termina por clavarle unas tijeras y así lo mata en defensa propia. Ella encarna a la mujer valiente y el vestuario que luce, se va tiñendo de colores fuertes con el desarrollar de las escenas, en el que se destaca 
un estupendo vestido rojo como la pasión que nutre por Mark. Pero sus ropas se van oscureciendo a medida que la trama se va tornando más sombría.

Ni loca, ni ladrona, ni fantasma. Margot es la mujer que no se rinde ni flaquea. Es una mujer que coge el toro por los cuernos.

\section{M de Manderley, de Motel Bates. Mansiones, palacetes, edificios: escenarios como personajes}

Manderley, la mansión de Rebeca (Rebecca), es un elemento poderoso en el film que lleva su nombre. Más allá de un simple escenario, el espacio funciona como un personaje principal en la trama. Grandiosa, la casa posee puertas enormes que contrastan con el frágil cuerpo de la protagonista, Mrs. Winter, los pasillos son muy largos y laberínticos, con cuartos ocultos y prohibidos ${ }^{6}$, las sombras se mueven y los cuadros parecen tener vida. $Y$ en el corazón del gran edificio pulsa el cuarto de Rebeca, el mayor, el más bello, el más siniestro. Para igualársele en pompa, solo la habitación da Sra. Bates, corazón pulsante de la mansión ubicada en la cima de la colina del Motel Bates, en Psicosis. Manderley constituye el escenario perfecto para dibujar un poder femenino avasallador sobre Mrs. Winter, un local aislado de todo, localizado a la orilla de un mar muy revuelto, metáfora de esta otra potencia femenina latente en la escritura hitchcockiana (la madre, la mujer siniestra y opresora, la imaginaria y fantasmática). En la lectura de González Requena, el mar “...se convertiría en esa amenazante y mórbida referencia que desde Rebeca en adelante pasaría a ser en la filmografía hitchcockiana -Náufragos, Sabotaje, Pánico en la escena, Vértigo, The Birds, Marnie la ladrona-" (Gonzalez Requena, Presentación, en Casanova Varela, 2007, p. 17). Mrs. Winter es prisionera de una mansión grandiosa, ocupada por la presencia avasalladora de Rebeca. Condenada a vagar por cuartos enormes, atravesar puertas descomunales, la muchacha está inmersa en un lugar que parece recordarle, a todo instante, cómo es insignificante. Pero la opresión que la casa ejerce sobre ella es fundamental en la composición de la trama. Junto a Sra. Danvers, Manderley compone la faz material para el cuerpo inmaterial y etéreo de Rebeca.

El escenario de Psicosis constituye un elemento especial en la obra de Hitchcock. La mansión es la metáfora, en arquitectura, de la propia Sra. Bates. Amenazadora, misteriosa, llena de recovecos interiores. La casa solo se desvelará, poco a poco, en las secuencias finales, a través de la mirada de Lila Crane, bien como la mujer siniestra que yace en su interior. El cuarto principal de la casa, donde habita la Sra. Bates se presenta como un escenario de una obra teatral, cuyo lugar central está ocupado por una gran cama de matrimonio con las marcas del cuerpo de la mujer sobre las sábanas. La buhardilla se revela como una habitación de niño, con juguetes que reproducen el universo infantil de Norman: un muñeco, una miniatura de la casa y otra del coche; un conejito de peluche sobre una cama pequeña y deshecha. Por fin, el sótano, cuyo acceso está precedido por puertas y escaleras que llevan a su siniestro interior. Allí se encuentra el esqueleto de la madre de Norman, que parece sonreír ante la sorpresa del espectador inmovilizado en su butaca.

En Festín Diabólico (Rope) el escenario del crimen es donde trascurre toda la acción del film. Es el mismo de la cena que la pareja de asesinos ofrece a algunos invitados. Ade- 
más, montan el bufé sobre el baúl en el que yace el cadáver de un chico. El escenario fue concebido como un apartamento situado en Manhattan con enormes ventanas de cristal asemejándose a un gran acuario donde todos los participantes de la fiesta parecen estar clausurados e imposibilitados de huir, como peces ornamentales. La sensación de que algo está a punto de estallar o emerger va aumentando con la llegada de la noche. El paisaje de Nueva York, visto a través la transparencia de los cristales, se va coloreando de tonos rojizos, sanguíneos, que se acentúan a medida que el clima de resolución del crimen va llegando a su zenit. La atmósfera de angustia se torna más densa a través del recurso del plano secuencia, pues el espectador vive la trama sin pausa ni cortes de escena.

Otro escenario poderoso en la filmografía hitchcockiana es el del Monte Rushmore. Uno de los momentos de mayor tensión del film North by Northwest transcurre en ese local emblemático de los EUA, con las efigies de los padres de la patria estadounidense talladas en la piedra: Washington, Jefferson, Roosevelt y Lincoln. La cima del monte Rushmore es el local perfecto para la cita entre el protagonista Robert Thornhill-Roger Kaplan (Cary Grant) y Eve (Eva Marie-Saint) al borde del precipicio. "Es un abismo lo que Roger-Robert ofrece a su Eve" (Casanova Varela, 2007, p. 187) sobre la cabeza de los dioses de la patria. Hitchcock saca el mejor provecho de los paisajes y los transforma en lugares cruciales para la trama: “¿Es necesario intentar utilizar de forma dramática todos los elementos locales, debemos servirnos de los lagos para ahogar a las personas, y de los Alpes para hacerlas caer en las simas de un glaciar!" (Hitchcock en Truffaut, Scott, 2004, p. 105).

El abismo y sus metáforas constituyen otro elemento fundamental en la obra de Hitchcock. Cuerpos que están a punto de desplomarse, o se desploman, imantados por este punto de atracción localizado en la profundidad de un lugar material o de uno mismo. Guy Haines (Farley Granger) está a punto de caer en la escena del carrusel desgobernado en Pacto Siniestro (Strangers on a train, 1951). En Psicosis, la caída de Arbogast (Martin Balsam) en la escalera de la mansión Bates, después de recibir una cuchillada de "la mujer misteriosa", es vertiginosa. Notamos este signo que se repite en los muchos cuerpos de personajes que se desploman en Vertigo o en el propio protagonista que a punto está de saltar al vacío durante toda la película, atraído por esa fuerza imperiosa que viene de su interior. En Rebeca, el inicio de la película ya introduce el tema del abismo al mostrar la silueta de un hombre al borde de un precipicio. Una sensación de vértigo invade el espectador cuando un plano detalle enseña sus pies listos para el salto fatal. Entre tanto una voz femenina lo interpela y él se detiene.

En el sueño de Ballantine (Gregory Peck) magníficamente ilustrado por Salvador Dali en Cuéntame tu vida (Spellbound, 1945), observamos esos elementos abisales con "su arquitectura -De Chirico es muy semejante-, las sombras alargadas, el infinito de las distancias, las líneas que convergen en la perspectiva ... los rostros sin forma..." (Hitchcock en Truffaut, Scott, 2004, p. 165). En Saboteador (Saboteur, 1942), la escena final en la Estatua de la Libertad sitúa a dos personajes al borde de un abismo descomunal. En la escena de la lucha en la antorcha de la descomunal estatua cuando el villano Frank Fry (Norman Lloyd) está suspendido en el vacío, Hitchcock muestra la manga del traje que se deshila a través de un primerísimo plano "se puede decir que su vida prende de un hilo" cómo ha subrayado Truffaut (Truffaut, Scott, 2004, p. 146). A continuación, Pat (Priscilla Lane) sostiene al héroe Barry Cane (Robert Cummings), que a punto está de caer también, lo 
sujeta por el brazo y lo sube al parapeto. Se trata de un boceto del penúltimo plano de North by Northwest, "pero enriquecida y completada por el gesto que lleva a los dos héroes directamente del monte Rushmore hasta la litera superior en el vagón-litera" (Truffaut, Scott, 2004, p. 150).

Pero nunca el escenario fue tan protagonista como en La Ventana Indiscreta (Rear Window). La película, que es metalenguaje del cine, muestra un ambiente que ofrece al espectador la metáfora de las múltiples escenas, personajes, acciones y el propio acto de mirar y/o dirigir un film. En los títulos de crédito las persianas van, poco a poco, subiendo, como cortinas en las salas de cine de aquellos años, para ofrecer un nuevo universo al espectador. El espectáculo va a comenzar para los espectadores convertidos en voyeurs.

La Ventana Indiscreta es, también, metáfora del acto de filmar. Jeff (James Stewart) es un fotógrafo inmovilizado en una silla por culpa de una fractura en la pierna. Solo le queda la visión de su vecindario con muchas ventanas abiertas que muestran las escenas que transcurren en el interior de cada apartamento. Un escenario con varias historias, dramas, un crimen y un voyeur. El protagonista es un hombre incapacitado, con una pierna escayolada, que no "ve" a Lisa Fremont, la mujer bellísima que tiene a su lado (Grace Kelly). Sólo la mira cuando se sitúa delante de su cámara, en el piso de en frente, víctima potencial de un asesino y está a la vera de la muerte. Es así, y solo así, cuando la ve. Y, como un estribillo en la filmografía hitchcockiana, también en La Ventana Indiscreta alguien -aquí será el héroe- quedará colgado al borde del vacío. Mirada y abismo, dos caras de la misma moneda en la escritura del mago del suspense.

\section{M de Mirada. Un ojo-abismo}

Hitchcock nombra como ningún otro director la cuestión de la mirada, de la insaciabilidad de mirar, del ojo como órgano deseante. En Psicosis, los grandes ojos de la protagonista Marion Crane (Janeth Leigt) están muy abiertos, casi nunca parpadean y solo se cierran para dormir. En la secuencia del encuentro con el guardia (Mort Mills) en la carretera, observamos los ojos como platos de la mujer en contraste con las dos elipses negras de las lentes en las gafas del policial que ocultan su mirada. En Rodríguez (2014) he subrayado que la escena muestra la oposición construida en un plano con la presencia de la mirada de la mujer y, en el contraplano, con la ausencia de la mirada en el hombre. Dos grandes superficies negras que nos remiten a los dos agujeros negros, también en lugar de ojos, de la calavera-madre revelada en el final del film. La metáfora ojo-abismo será resaltada en el desagüe de la ducha en fusión con el gran ojo sin vida de Marion en la célebre secuencia del baño.

El ojo es, en efecto, el órgano mismo del cine, el lugar genético y pasional que se inflama en visiones alucinadas al proyectarse en la pantalla. Ese ojo rasgado, arrancado a picotazos, vaciado, convertido en cuenco de desagüe o en cavidad de la calavera sugiere la destrucción de la ficción, de esa delgada película de agua, agua de nuestros sueños, que separa el sueño de la realidad. Y bien, la irrupción de lo siniestro, caída del abismo, visión del abismo, percepción alu- 
cinada desde el ojo de lo que carece de ojo, visión tremenda de una cuenca sin ojos, eso es la plena realización de la ficción [...] (Trías, 2006, p. 108).

Los grandes ojos plasmados en la pantalla son el espejo de los nuestros que los observan. Esta mirada encuentra su perfecta figuración en otra secuencia magistral de Psicosis. Después de conferir y comprobar que Marion firmó un nombre falso en el libro de registros, Norman se dirige a la salita de los pájaros y cierra la puerta. Percibimos que el aposento es contiguo a la habitación de la mujer. La escena muestra a Norman, rodeado de aves de rapiña, retirando un cuadro de la pared. Se trata de una representación barroca de "Susana y los viejos" del pintor holandés Mieris, el viejo. El tema de la pintura fue inspirado en el relato bíblico que aborda el acto de observar y de los límites para la mirada (Rodríguez, 2012, 2014).

$\mathrm{Al}$ apartar el cuadro de la pared se muestra un gran agujero y, en su interior, se oculta otro menor. Los agujeros son irregulares, como hechos a zarpazos o picotazos. El hombre se aproxima para mirar cómo se desnuda la mujer. Un gran plano detalle del globo ocular en perfil aparece ocupando mitad de la pantalla, enorme, devorador. El agujero irregular, una fisura en la pared, ocupa la otra mitad del plano. Esta imagen emblemática es, sin duda, la mejor metáfora plástica para la pulsión escópica. Ese plano sintetiza también la fusión de la mirada del espectador con la del personaje, reducido a la posición de voyeur.

Cuando Norman espía por el agujero en la pared, el espectador ve a si mismo mirando, y, por su parte, se ve siendo observado, pues, en el ámbito del contraplano nos identificamos con esta mujer amenazada. Es de la pasión y del riesgo de mirar de que nos habla Hitchcock en esta escena antológica. De mirar y ser mirado, del acto de observar y de ser cuerpo que atrae las miradas.

Otra película que resalta el tema de la mirada, con énfasis en el ojo y sus metáforas, es Vértigo. En los títulos de crédito, después de mostrar un gran plano detalle de un labio femenino, la cámara se eleva en busca de los ojos. Ellos miran a derecha y a izquierda asombrados. La cámara enfoca el ojo izquierdo que se vuelve, de pronto, rojizo. Del interior dela pupila algo empieza a surgir. "Como del fondo de un abismo cósmico, empiezan a brotar formas que invaden toda la pantalla sugiriendo un espacio infinito y absoluto donde la imagen envuelve en espiral al espectador", enfatiza Trías (2006, p. 90). El autor resalta que el abismo está en los ojos de Scottie y de ellos no se separará en todo el film. La sensación de vértigo del personaje se revela en su mirada de reojo, pues, en el contracampo se encuentra algo que teme y al mismo tiempo le fascina: el abismo profundo o el rostro de la fantasmática Madeleine. Señala Trías: "Un ojo es la primera imagen como hemos visto de Vertigo: un ojo que prefigura un abismo o es el abismo. Ese ojo-abismo, mostrado en Vertigo en el registro pasional, reaparece en Psicosis en el registro macabro, siniestro" (Trías, 2006, p. 107). Trías afirma que el abismo sube, el abismo se eleva, se acerca a los ojos quien lo mira, se mete y se introduce en los ojos quien lo ve. "Un ojo así quiere que ese abismo se encarne, se materialice, se proyecte en un rostro, sea el propio abismo un rostro, sea el propio abismo un ojo" (Trías, 2006, p. 94).

Una de las escenas más impresionantes de la película Los Pájaros es cuando la madre del protagonista se encuentra con el cadáver del vecino al que los pájaros le han dejado vacías las cuencas de los ojos. La irrupción de lo siniestro puede percibirse en las cuencas sin ojos 
en las películas que hemos señalado, pero también en Cuéntame tu vida en la escena diseñada por Dali del sueño del protagonista cuando unas enormes tijeras cortan imágenes de grandes ojos.

Mirada y abismo también se encuentran en North by Northwest. En la impresionante secuencia en el Monte Rushmore, que ya hemos señalado, Eve y Roger están colgados, sujetados por un brazo en el ojo de piedra del presidente Jefferson. Pero, el ojo petrificado no los observa, su mirada se dirige al otro lado, hacia algo distante de ellos. En el plano siguiente un abismo los aguarda. De nuevo el tema del vértigo en conexión con la mirada como ocurre en Vértigo.

\section{M del Movimiento en espiral}

El movimiento que más se destaca en la obra de Hitchcock es aquel que conduce al espectador a una sensación de estado hipnótico. La figura de la espiral, sus metáforas y los movimientos rotatorios están presentes de forma significativa en muchas películas del director. Este elemento nos lleva no solo a la figura plástica del mismo, sino también a aquella "espiral de sentidos que constituye el recorrido textual" de la obra del director, como resalta Wood (1968, p. 256).

Este elemento nos conduce a un vórtice, a una vorágine, al movimiento de la locura e introspección, presentes en el interior del sujeto, en sus pasiones desbocadas, sus deseos ocultos, en los laberintos del ser. El punto de partida del film Enviado Especial (Foreign Correspondent, 1940) es una escena en la que aparecen algunos molinos. Uno de ellos posee una pala que gira en sentido contrario a la dirección del viento. Este es el movimiento del agua en el desagüe de la bañera en Psicosis y de la cámara en el ojo de Marion Crane. Es un movimiento giratorio él de la silla de la Sra. Bates en la escena del descubrimiento del esqueleto en el sótano.

Lo último que vemos de Marion al ser asesinada por Bates es el ojo. Ese ojo, al extinguirse, deja paso a una de las más crueles asociaciones que el cine ha producido: el desagüe de la bañera, la espiral de agua de la ducha deglutida por el desagüe. Es la espiral infame y nauseabunda que forma el reverso en negro, el contraplano negativo de la espiral pasional de Vertigo: espiral de los carteles introductorios surgidos del fondo de la pupila izquierda del ojo de la mujer, espiral de la escalera de caracol, espiral del moño de Madeleine y de Carlota Valdés (Trías, 2006, p. 108).

Lo que está inscrito en el fondo de la espiral es un agujero negro, un lugar siniestro, como el que surge en los títulos de crédito de Vértigo. Martin Arias afirma que “[...] ese ojo, virado en rojo pasión, en rojo sangre, se abismaba de inmediato, a través de la emergencia de la espiral, en cuyo centro aparece el terrorífico agujero negro de lo real" (Martin Arias, 1997, p. 133).

El moño de la protagonista, el bucle de Carlota, es el objeto fetiche de Scottie, como ha señalado Basilio Casanova (2017). En Vértigo, el detective, en su ansia de transformar a Judy 
en su fantasmática Madeleine, no descansará hasta que ella no sujete su pelo en el moño, esa espiral de sus deseos más primarios. El bucle va a resurgir en la obra de Hitchcock en Psicosis, en la calavera de la Madre de Bates, al final del film.

La espiral también está presente en el sueño de Scottie, una animación en la que la silueta de su cuerpo se abisma en un movimiento helicoidal de locura, de flores y de colores saturados. La espiral de la escalera del campanario es una imagen que le producía tal vértigo a Scottie que no pudo salvar a Madeleine de la muerte ${ }^{7}$.

El movimiento en espiral es una forma plástica para nombrar el universo narcisista, cerrado, esquizoide en los que circulan los relatos aquí señalados. La espiral manierista presente en la escritura hitchcockiana encuentra un eco en este texto del poeta Fernando Pessoa: "Una espiral es un espejo de imágenes que se aproximan y se apartan, una repetición infinita de uno mismo, de sus fragmentos. Es una manera de revolverse, de romperse y de centrifugarse" (Pessoa, 1999, p. 79).

\section{M de Melancolía. La soledad del personaje, el genio del director}

Como hemos subrayado, la película La Ventana Indiscreta es un caso ejemplar de metalenguaje, del cine dentro del cine. En las muchas ventanas abiertas delante del protagonistaespectador ocurren historias. Muchas de ellas son facetas de la soledad humana. Las escenas muestran dramas de los habitantes de las grandes ciudades reducidos a la condición de peces atrapados en sus acuarios con ventanas de cristal. El protagonista Jeff (bien como el espectador) se identifica con cada historia, con cada uno de estos seres, incluso con el perrito. Los personajes observados pasan de una soledad cotidiana hasta una melancolía profunda que vera el suicidio. Y el fotógrafo, metáfora del director de cine, encarna, en este caso, al propio Hitchcock.

Aristóteles fue quien postuló por primera vez una conexión entre el humor melancólico y un talento superior para las artes y las ciencias. Rudolf e Margot Wittkower (1985) resaltan que solo el homo melancholicus es capaz de subir a las alturas más sublimes y, así mismo, está propenso a situaciones que rayan la locura. En sus reflexiones sobre Lo bello y lo sublime, Kant (2008) afirma que el ser melancólico de temperamento está más capacitado para percibir lo sublime. El equilibrio precario del melancólico lo situaría entre la genialidad y la locura. Según Kant, ese es el estado ideal para captar lo sublime. Hago estas consideraciones teóricas para poder postular la tesis de que el director Hitchcock era un ser melancólico, cuya obra raya lo sublime en relatos que zambullen en la locura. Si partimos de La Ventana Indiscreta como metalenguaje, como obra dentro de la obra, Hitchcock es el genio cuya "locura" es llevar su pasión por el cine hasta las últimas consecuencias. En el caso de Jeff, no basta con observar atentamente, tener una posición pasiva desde su mirada, tiene que intervenir, cambiar el rumbo de los acontecimientos, vivir y experimentar todas las pasiones.

Mientras dirigía a las actrices, Hitchcock exigía de ellas lo máximo hasta el punto de alcanzar la perfección absoluta. En la escena de la ducha en Psicosis, cuando Janet Leight era apuñalada por la Sra. Bates, hasta que la chica no alcanzó el zenit de un terror real, hasta que no dio un grito tremendo próximo a la verdad de vivir un crimen, el genio no se dio 
por satisfecho. ¿Qué es lo que buscaba? ¡Lo Real! El genio logró rozar el fondo del ojo, el agujero negro, lo siniestro: "cumplimiento en lo real de un sueño que al fin se revela pesadilla” (Trías, 2006, p. 115).

La escena filmada es, casi sesenta años después del estreno del film, una obra de arte. La secuencia de la ducha es considerada un marco en la historia del cine, no solo por los cortes y montaje innovadores, sino también por la extrema asociación que el director hace entre el ojo del espectador y la cámara que filma la mujer. Podemos observar a lo largo de la secuencia que las líneas diagonales dibujadas por los hilos de agua que salen de la ducha aparecen en contraposición a los movimientos, también diagonales, de los golpes del cuchillo. Así, la sucesión de líneas que se cruzan en el espacio ayuda a cortar a la mujer como las propias cuchilladas de la sombra asesina. El sonido estridente de los violines, presentes en la banda sonora de Bernard Herrmann, también colabora con la tarea de herir profundamente el cuerpo de la mujer con una serie de notas agudas y fragmentadas. Y, para completar, los múltiples cortes en el montaje de la secuencia son determinantes para fraccionar y fragmentar el cuerpo de la mujer en sus partes: rostro, piernas, tronco, manos y boca. Así como, nuestra mirada se confunde con la cámara y descuartizamos el cuerpo femenino y asumimos, por eso, una identificación con el asesino -o el director- presente en la escena. Es nuestro ojo, es nuestra mirada la que goza cortando y decoupando el cuerpo de la mujer en una multitud de planos. Pues la fragmentación de la planificación se convierte en sinónimo de descuartizamiento. El cuchillo, los hilos de agua, las notas agudas de los violines y los cortes de la secuencia se materializan en la más perfecta metáfora de nuestra mirada. Escena revolucionaria. Con Hitchcock el suspense adquiere una nueva dimensión. De una u otra forma, todos los directores de este género post-Hitchcock lo homenajean en sus películas.

Así como Scottie en Vertigo, el director sube a la torre más alta, pero...

¿Qué más quiere, qué más puede desear, si cuanto deseaba se ha hecho realidad? Eso que vemos ahora: un hombre que ha satisfecho en lo real su deseo; la imagen misma del efecto que produce en el sujeto ese poder y esa libertad tan afanosamente buscada (Trías, 2006, p. 115).

La soledad y la melancolía van a brotar en la obra de Hitchcock, en los personajes retratados, en historias de lo cotidiano, en los escenarios exteriores e interiores. Hemos encontrado una relación de la obra hitchcockiana con la pintura de Edward Hopper ${ }^{8}$ y, creemos, ha llegado el momento de costurar los hilos que tejen esa tesitura con las reflexiones sobre la soledad y la melancolía. Es impresionante la relación pintura-cine en Hitchcock, pero cuando convocamos a Hopper este diálogo estético en intenso.

En La Ventana Indiscreta encontramos escenas que son la materialización en movimiento de muchos cuadros del artista estadounidense. Hopper fue quien mejor pintó el drama de la soledad del hombre moderno y sus momentos de melancolía frente a la ciudad que pulsa y vibra delante de sus ventanales. En La Ventana Indiscreta, las pequeñas historias también se narran a través de los cristales de las ventanas. Cortinas cerradas cuentan el sexo de la pareja en luna de miel. Mientras otras se cierran para ocultar el crimen. Son como cortinas abiertas para un palco donde danza la bailarina o toca el pianista. Son como fotogramas 
de una película en 3D. Las ventanas son personajes concretos, secretos, indiscretos. En La Ventana Indiscreta observamos la soledad del artista plástico, la del músico, de la bailarina e, incluso, la del asesino. La noche en La Ventana Indiscreta es de los solitarios, los insomnes, los voyeristas. Hallamos momentos semejantes en la obra de Hopper. El cuadro Automat, de 1927, muestra a una solitaria mujer con sombrero en un restaurante tal como la vecina de vestido verde lo hace en una cena en su salón, en la película de Hitchcock. En Night Windows, de 1928, Hopper pinta un lienzo donde se observa un edifico a corta distancia con una ventana y sus cortinas mecidas al viento, mientras por la otra se vislumbra a una mujer de espaldas con una lencería transparente en tonos de rosa. Es una escena muy similar a la de La Ventana Indiscreta cuando vemos a la bailarina, con trajes semejantes y en una postura de cuerpo casi idéntica, observada por Jeff. En Hotel room, una mujer está sentada en una habitación de hotel y tiene libro abierto al que parece leer, pero su rostro está ensombrecido. Una imagen similar es mostrada en la película a través de una rendija de una ventana del edificio de en frente. Hopper en Room at New York muestra a una pareja donde cada uno está a sus asuntos. Él lee el periódico y ella está melancólica, inmersa en sus pensamientos mientras teclea un piano. Observamos una escena muy semejante cuando el artista está junto a una mujer en su piso en La Ventana Indiscreta.

En nuestra investigación nos deparamos también con otras obras del pintor estadounidense que dialogan con filmes de Hitchcock. En muchas películas del director encontramos planos casi idénticos a la pintura de Hopper, un diálogo estético de profundas conexiones estructurales y de sentido. En Compartiment C, car 293, 1938, una mujer que usa vestido y sombrero azules lee solitaria en su vagón en un tren. En 39 escalones (1935) observamos a Pamela (Madeleine Carrol) a bordo de un tren en la misma postura y lugar del cuadro de Hopper. El encuadramiento, la iluminación, la composición y la actitud de los personajes transmiten el mismo sentimiento de soledad, tanto en la pintura como en el film. Ambos artistas poseen formas muy semejantes para crear imágenes y situaciones. Office at Night, de Hopper (1940) muestra a una muchacha trabajando por la noche, de pie delante de un archivo, mientras su jefe está en su mesa, leyendo. El cuadro nos recuerda una secuencia de Marnie la ladrona, cuando la protagonista trabajaba después del expediente para su jefe enamorado. La oficina y la atmósfera de una relación llena de interrogantes del cuadro está presente también en el film de Hitchcock.

Queensborough Bridge (1913) representa el nuevo puente Manhattan-Queens, mientras se ve una mansión que parece oprimida por la gran construcción y aislada en la orilla opuesta. En Sombra de una duda (Shadow of a Doubt, 1943) un puente que conecta Jersey City a Newark es muy similar al que retrató Hopper y sirve de telón de fondo para una merienda de dos hombres solitarios.

Los edificios de Hopper son una fuente de inspiración constante para Hitchcock. En House by the RailRoad (1925) la atmosfera asustadora y enigmática también está presente en Psicosis. El cuadro fue una verdadera inspiración para la mansión de los Bates. El apartamento-acuario de Festín Diabólico nos remite al cuadro Nighthawks (1942), de Edward Hopper. La escena de la pintura retrata tres personas sentadas en la barra de un bar mientras les sirve un camarero. Pero la diferencia es que en el escenario de Hitchcock el espectador se localiza dentro del propio acuario y no como un observador pasivo o un paisano situado en el ambiente externo, como en el cuadro de Hopper. 
Como en una pintura de Hopper, la historia de La Sombra de una Duda se narra con frecuencia a través de las ventanas, y por las propias ventanas. Las luces se encienden y se apagan y revelan detalles del enredo. En Vértigo, la escena en que Madeleine mira por una ventana de su habitación en el hotel nos lleva a la pintura de Hopper Cape Cod Morning, 1950. En ella la joven situada delante de una gran ventana tiene, como Madeleine, la mirada perdida en el horizonte. ¿Locura, alejamiento o soledad? La verdad es que las dos protagonistas poseen una mirada distanciada y misteriosa.

Hopper posee, como Hitchcock, la mirada de voyeur para captar los momentos privados, las situaciones misteriosas, solitarias e íntimas. La pintura de Hopper respeta un cierto alejamiento, una distancia necesaria para no perturbar el objeto representado. En Summer interior, de 1909, el pintor muestra el interior de una habitación con una cama deshecha y una mujer desnuda en el suelo en postura de total desconsuelo (la imagen nos conecta con la de Marnie deshecha después del rechazo de su madre). Pero el pintor toma prudentemente una distancia necesaria para no perturbar a la mujer en su momento de melancolía. El cuadro The City, de 1927, parece un fotograma de la secuencia inicial de Psicosis, en plano general, cuando la cámara busca la ventana del cuarto del hotel donde se encuentran Sam y Marion Crane. Por su parte, Room for Turists es una mansión que posee una arquitectura muy parecida a la casa donde se hospeda el Tío Charlie, de La Sombra de una Duda. Pero, una vez que el cuadro fue pintado dos años después del lanzamiento del film es probable que el pintor se haya inspirado en el film para concebir su lienzo.

\section{M de Materialización y de Metáfora}

La investigación está lejos de concluir. El corpus de filmes de Hitchcock posee una inagotable fuente de estudio. Las imágenes analizadas en las películas del período estadounidense poseen camadas profundas arraigadas a elementos icónicos que se repiten como un refrán. Tratamos de tejer aquí un texto cruzando los hilos con los matices que se repiten en la obra de este increíble director. Y, equipados de los hilos y hebras, movidos por la aguja del sentido, intentamos tejer un tapiz con el mismo entusiasmo y pasión con los que Aracne hizo los suyos. Partiendo de un centro, un núcleo, imprimiendo un dibujo helicoidal, que es el movimiento por antonomasia de Hitchcock, construimos nuestro entramado. Así vimos emerger un tejido cuyas conexiones nos llevan a lo más íntimo del sujeto: la madre, la mujer, la melancolía, la mirada, la muerte... La inicial M, en mi opinión, no es una mera coincidencia, sino que se trata de la $\mathrm{M}$ de la Metáfora de nuestros más recónditos lugares, nuestros secretos, nuestros deseos. Materialización de un edificio que, a partir de los fragmentos descubiertos en el texto hitchcockiano, vamos poco a poco reconstruyendo. Es algo que resuena y vibra en lo más íntimo de uno. Un punto de encuentro entre obras de arte y la trama de nuestros conflictos interiores. 


\section{Notas}

1. La historia se desarrolla en el espacio pequeño del apartamiento de los Milland, pero el director utiliza varias técnicas para crear profundidad. Él concibió un foso para que la cámara pudiese estar al nivel del suelo, por ejemplo. La película fue rodada en el sistema de relieve Polaroid, sistema binocular, el conocido 3D. Sesenta años después el film fue remasterizado y lanzado en Blu-ray para que los efectos em 3D fueran más nítidos.

2. Segundo Jesús González Requena (2006), el manierismo como escritura cinematográfica está muy próximo del modelo manierista de las Bellas Artes. Difiere, pues, del modelo renacentista clásico. Subvierte no solo la forma clásica, sino también el contenido. En este modelo ocurre la pérdida del universo simbólico del relato que construye, la pérdida del orden de valores y ser produce un enflaquecimiento del relato clásico.

3. Sugiero la lectura del capítulo de mi libro "Além do espelho" (Rodríguez, 2014), en el que analizo en profundidad la película Psicosis.

4. Hemos tratado del diálogo del cine de Hitchcock con la pintura en Trama y Fondo (relato de Susana) y más adelante hablaremos de los encuentros estéticos de la obra de Edward Hopper y el cine de Hitchcock.

5. Ofelia (1851-1852), de Sir John Everett Millais. Tate Modern, Londres.

6. La mansión Manderley guarda una semejanza significativa con el palacio del Cuento de Barba Azul y su cuarto prohibido.

7. Hitchcock intensifica esta sensación en el protagonista y en el espectador a través de la técnica de zoom-out y Dolly-in con un plano cenital de las escaleras.

8. Todas las obras del pintor están disponibles en el sitio: https://www.edwardhopper.net/

\section{Referencias bibliográficas}

Calabrese, O. (1997). Como se lê uma obra de arte. Coimbra: Edições 70.

Casanova Varela, B. (2017). Desmentida, fetichismo y perversión en Vértigo (1958). Rev Med Cine [Internet] Disponible en http://revistas.usal.es/index.php/medicina_y_cine/ article/viewFile/16529/17156 Consultado el 25 setiembre 2017.

Casanova Varela, B. (2007). Leyendo a Hitchcock. Análisis textual de North by Northwest. Valladolid: Castilla Ediciones.

Castro de Paz, J. L. (1995). “Los ojos atrapados en el lienzo: entre el enigma y la pasión (a propósito de una secuencia de Vértigo, 1958, Alfred Hitchcock”. El análisis cinematográfico. Modelos Teóricos metodologías, ejercicios de análisis en González Requena, (org) Madrid, Ed. Complutense, p. 225-269.

Martin Arias, L. (1997). El cine como experiencia estética. Valladolid: Caja España.

Martin Arias, L. (1998). "Visiones de Hitchcock" en Diván el terrible, n², Madrid.

González Requena, J. (1995). Frente al texto fílmico; el análisis, la lectura. A propósito de El manantial de King Vidor, en González Requena, Jesús (org.) El análisis cinematográfico, Madrid, Editorial Complutense, p. 11-45, 1995.

González Requena, J. (1996). “El texto: tres registros y una dimensión”. Trama y Fondo, Madrid, v. 1, n. 1, p. 03-32. 
González Requena, J. (2006). Clásico, Manierista, Posclásico, Los modos del relato en el cine de Hollywood. Valladolid, Castilla Ediciones.

Kant, I. (2008). Observaciones acerca de lo bello y lo sublime. Madrid: Alianza Editorial.

Lacan, J. (1986). Hamlet por Lacan. Campinas: Unicamp/Escuta Editora.

Pessoa, F. (1999). O livro do desassossego. São Paulo: Companhia das Letras.

Rodríguez, V. B. C. (2014). Além do espelho. Análise de imagens de arte, cinema e publicidade. Curitiba: Appris.

Rodríguez, V. B. (2012). "El relato de Susana y los viejos. Representación en la pintura y resonancias en Hitchcock" en Revista Trama y Fondo, n o 31, pp. 65-76.

Samain, E. (2011). “As 'Mnemosyne(s)' de Aby Warburg: entre antropologia, imagens e arte" Revista Poiésis, Florianópolis, n. 17, p. 29-51.

Teixeira, F. C. (2010). "Aby Warburg e a Pós-vida das Pathosformeln Antigas". História da Historiografia, Ouro Preto, n. 5, p. 134-147.

Trías, E. (2006). Lo bello y lo siniestro. Barcelona: DeBolsillo.

Truffaut, F. (2003). El cine según Hitchcock. Madrid: Alianza editorial.

Truffaut, F.; Scott, H. (2004). Hitchcock/Truffaut: entrevistas. São Paulo: Companhia das Letras.

Wood, R. (1968). El cine de Hitchcock. México: Era.

Wittkower, R.; Wittkower, M. (1985). Nacidos bajo el signo de Saturno. Madrid: Cátedra.

Abstract: This essay brings together the film production of Alfred Hitschcock with other aesthetic works from an interdisciplinary perspective.

Keywords: Hitschcock - aesthetics - textual tissue - reading.

Resumo: Este ensaio reúne a produção cinematográfica de Alfred Hitchcock com outros trabalhos estéticos de uma leitura interdisciplinar.

Palavras chave: Hitchcock - estética - tecido textual - leitura.

[Las traducciones de los abstracts fueron supervisadas por el autor de cada artículo] 